\title{
Editorial
}

\section{Gillian Sands}

It is with great sadness that I have to report the tragic death of Gillian Sands on $31^{\text {st }}$ January at the age of 30 . Gillian was a key and long-standing member of the Editorial Board. For some years, she had been jointly responsible for the Current Awareness column for LIM. It was always immaculately produced and Gillian never missed a deadline. Shortly before her death she had agreed to become Deputy Chair and I was looking forward greatly to working with her when she eventually took over from Caroline Mosley.

All the Editorial Board members were extremely shocked to hear of Gillian's death and many messages have flowed in, paying tribute to her qualities of kindness, thoughtfulness and her legendary efficiency in always carrying through any tasks entrusted to her by the Board. She was a much-loved colleague and friend to us all. Her network of friends and professional associates around the world are now, and will be in the future, a continuing testament to her ability to nurture others. She could be relied upon to come up with suggestions for articles and for potential authors and I, for one, relied heavily upon her judgment. She stood on the threshhold of a brilliant career and it is so sad that she will not live to realise it.

The Autumn issue will contain a full obituary of Gillian and will be devoted to the memory of her life and work. Several of her friends and colleagues have already agreed to contribute to the issue and we plan to give it an international theme to reflect one of Gillian's professional interests.

\section{Donald Raistrick}

It would not be fair to allow Don's retirement to go unnoticed in these pages. Don was Editor of the Law Librarian for eight years between 1976 and 1984 and a member of the Editorial Board between 1976 and 1988. He was also on the Publications Committee from 1975 to 1992 - a long stint by anyone's standards. He was heavily involved in other BIALL activities for many years, as well as being a prolific author on his own account. His publication Lawyers Law Books was a bible for those of us working in law librarianship in the 70 s and 80 s, as was his Index to Legal Citations and Abbreviations first published in 1981. For his swansong, Don has written an article for us on the challenges he faced whilst spending his entire working life in the Lord Chancellor's Department/ Department of Constitutional Affairs. We also publish some pictures of Don meeting the Queen to receive his $\mathrm{MBE}$, a fitting close to a long career in legal information work.

\section{Bar Vocational Course}

Over the years very little information has appeared in either the Law Librarian or Legal Information Management about the training of barristers, but there have been many articles about the LPC, trainee solicitors, legal research courses for solicitors etc. In this issue we have tried to redress the balance. Peter Clinch, who has been the adviser on library and information resources and legal research skills training to the General Council of the Bar for England and Wales since 1996, has written a comprehensive article on the routes to qualification for barristers, how the legal research element of the course is delivered, and the role which law librarians are playing in training potential barristers in these techniques, which are of course a key weapon in the armoury of the qualified and effective barrister. Michael Chapman, who runs the Bar Vocational Course at the Inns of Court School of Law, now part of City University and the largest provider of the BVC in this country, has written an extremely interesting article explaining how the course is delivered via state of the art technology, including a virtual learning environment and computer systems where the teacher can take over the student's computer and check out how he is doing with a particular piece of drafting or other exercise. A bit different from the days of sitting in lecture theatres and writing notes!

\section{Freedom of Information}

We have commissioned four articles on different aspects of the new Fol regime, as this seems to be a topic uppermost in our colleagues' minds at present. Michelle Wyer explains what systems the Inland Revenue has set up for dealing with requests for information under the Act, together with an outline of the staff training involved. Anne Jones, Assistant Information Commissioner for Wales, tells us about the impact of the Act there and gives some details of the kinds of requests which are being filed. Victoria Moody from the Information Commissioner's Office in England explains the nuts and bolts of the Act and Jackie Grey a senior solicitor from Walker Morris in Leeds describes how the Act is affecting local authorities. 


\section{Editorial}

\section{Practical checklists}

The Editorial Board felt that it would be useful to start a series of practical checklists and this issue sees the first of these articles. We are asking leading and highly experienced legal information professionals to contribute short practical guides or checklists to the managerial aspects of our jobs. The first checklist has been written by Vanessa Forster of Cobbetts and covers interviewing techniques. Vanessa has many years of interviewing experience both in her job running Cobbett's training function and also working for the $C A B$ for nine years.

\section{From our own correspondent}

Dave Rogers from Sidley Austin's Chicago Office has very kindly agreed to be our foreign correspondent for this issue and the topic he has chosen of Fol fits in perfeclty with our major theme.

Dave will be keeping us in touch with events in the US on a regular basis in the future.

\section{Current awareness}

Due to Sam Weston-Smith's absence on maternity leave, Katherine Read of the IALS has nobly produced the column as a solo effort and we are very grateful to her.
Sam has decided not to return to work and her replacement will be John Greenhead, also from the IALS. The Board is very grateful to Sam for all her efforts, and we wish her all the best in her new role, and to John for volunteering to take over at short notice.

\section{Peer reviewed articles}

We are planning to introduce a refereed section to the journal and are currently calling for contributions. We would like to emphasise that only one article per issue would be refereed. The following is an extract from the call for papers issued on LIS-LAW recently:-

"We are introducing a refereed section to the journal and are currently calling for contributions. The journal looks to provide commentary and analysis on all aspects of legal information management. While being focused on the four jurisdictions within the British Isles, articles discussing legal information management issues and developments in other jurisdictions are welcome. Articles on legal education will also be of interest where they touch on legal research issues or provision of library or similar support services

Authors interested in these areas are invited to submit articles or to contact the editor to discuss ideas for articles. Articles for publication should be submitted for consideration to the Editor".

\section{Christine Miskin}

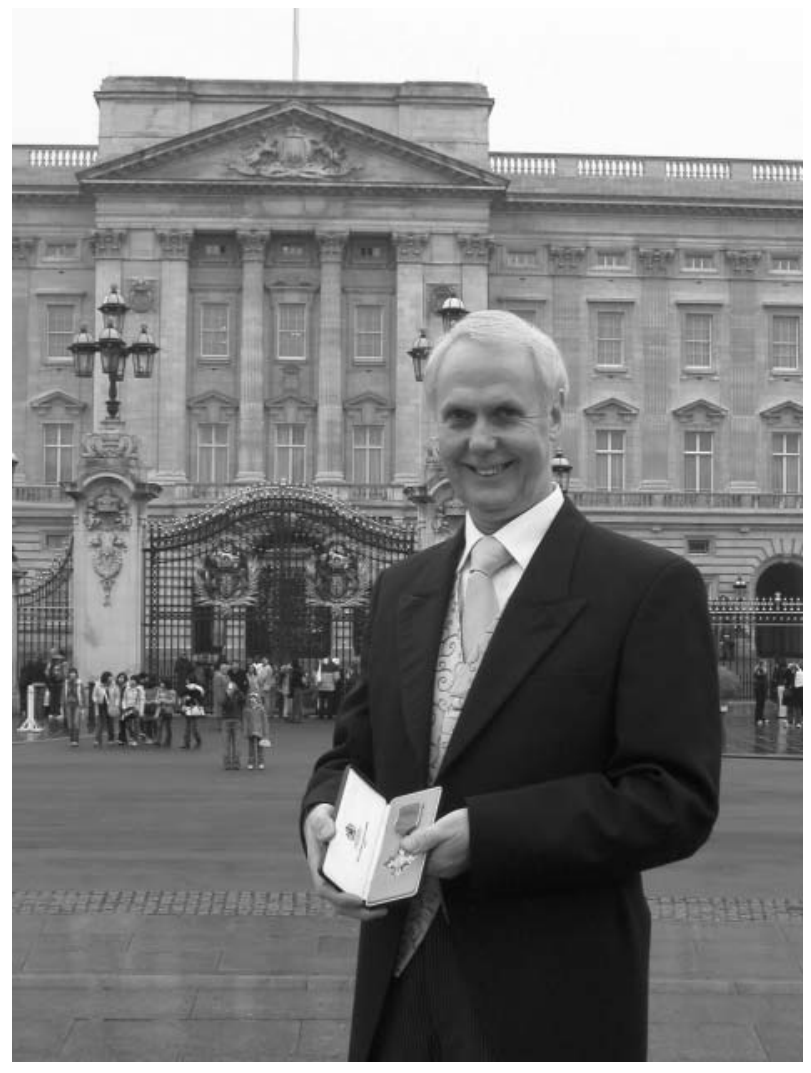

Don Raistrick outside Buckingham Palace with his MBE 